\title{
René Armand Dreifuss
}

R ené Dreifuss, um dos mais brilhantes cientistas sociais brasileiros de sua geração, faleceu em 4 de maio de 2003, em sua casa.
Lutando durante quase três anos contra grave enfermidade, e tendo se submetido a duas operações no cérebro para extirpar o tumor que finalmente se mostrou invencível, jamais deixou de exercer suas atividades como professor e pesquisador até pouco antes de sua morte. Fez questão de continuar, em sua residência, sob penosas condições, dando aulas para os alunos de Relações Internacionais da Pós-Graduação em Ciência Política da UFF. Em dezembro último, já apresentando sérias dificuldades para se locomover e para falar, fez questão de comparecer ao seu local de trabalho para presidir a banca de Mestrado que julgava a tese de um estudante querido. Nessa oportunidade, sua mulher, Estrela Bohadana, lia em voz alta os comentários e indagações preparados por ele. Na intermitência da doença, encontrou forças para viajar pelo país e para o exterior, satisfazendo apenas alguns dos inúmeros convites, que sempre estavam sobre sua mesa de trabalho, feitos pelas mais prestigiadas instituições de ensino e pesquisa. Encontrando brechas no tempo que lhe era escasso, e vencendo o cansaço profundo - causado pela ingestão de, ou a exposição a, drogas poderosas -, descobriu suficientes motivações para es-

DADOS - Revista de Ciências Sociais, Rio de Janeiro, Vol. 46, nº 1, 2003, pp. 195 a 197. 
crever seu último livro, contando sempre com a ajuda inestimável de sua companheira. Com efeito, Matrizes do Século XXI dará continuidade aos seus penetrantes estudos e reflexões sobre o mundo contemporâneo, exposto às irrupções científicas e às explosões tecnológicas sob a égide da ordem globalizada e que, por isso mesmo, estão a requerer a elaboração de novos paradigmas perceptivos. Sua mulher, seus amigos e colegas da UFF e alhures por certo irão se encarregar de publicá-lo.

René teve uma vasta e sólida formação intelectual. Nascido em 1945 em Montevidéu, Uruguai, formou-se em história e ciência política pela Universidade de Haifa, Israel. Obteve, na Grã-Bretanha, em 1974, sempre na área da ciência política, o título de mestre na Universidade de Leeds, e o de doutor na Universidade de Glasgow, Escócia, em 1980. Seu currículo exibe uma ampla e diversificada participação em palestras, seminários, conferências, simpósios etc., tanto no Brasil como no exterior. Poliglota (falava e escrevia em espanhol, português, inglês, francês, alemão e hebraico), publicou, em revistas brasileiras e internacionais, várias dezenas de artigos sobre assuntos políticos nacionais e latino-americanos, Forças Armadas e sociedade e, nos últimos tempos, cultivando a abordagem multidisciplinar, relações internacionais. Escreveu vários livros, sendo logo o primeiro um best-seller, que vem merecendo sucessivas edições, 1964: A Conquista do Estado (Vozes, 1981). Seguiram-se a Internacional Capitalista (Espaço \& Tempo, 1986); O Jogo da Direita na Nova República (Vozes, 1989); Política, Poder, Estado e Força-Uma Leitura de Weber (Vozes, 1993); A Época da Perplexidade (Vozes, 1996).

Dentre os diversos cargos por ele ocupados, destacam-se os de professor de ciência política da UFMG (1980/1984), o de membro-fundador do Núcleo de Estudos Estratégicos da UNICAMP, o de pesquisador-visitante da COPPE/UFRJ (1984/1986), o de assessor-técnico da Fundação Escola de Serviço Público (FESP) do Rio de Janeiro e, até há pouco tempo, o de conselheiro ad hoc do Ministério das Relações Exteriores. A partir de 2000, foi coordenador do módulo "Mudanças de Paradigmas de Ciência \& Tecnologia" no Instituto Virtual Internacional de Estudos das Mudanças Globais da COPPE/UFRJ. Desde 1986 até o seu falecimento, foi professor do Departamento de Ciência Política da UFF, lecionando na graduação e na pós-graduação, onde, nos últimos anos, recebia da FAPERJ bolsa de apoio para suas pesquisas. Na UFF, ainda, com o apoio do reitor José Raimundo Romeo, tive a 
oportunidade de com ele ser o fundador do NEST (Núcleo de Estudos Estratégicos), tendo René exercido por muitos anos o cargo de coordenador-chefe.

O autor destas breves anotações foi colega e amigo pessoal de René Armand Dreifuss por 27 anos. Fui, assim, testemunha viva do acidentado périplo cumprido pelo profissional exemplar, cultor de notável disciplina de trabalho, mas que, antes de mais nada, foi dotado de raro talento para o entendimento dos intricados e tumultuados processos que caracterizam a existência social da vida humana. Como homem, René viveu como veio a morrer: valorizando a dignidade como valor central de sua conduta, democrata convicto, cientista interessado em investigar e buscar soluções para os problemas da pobreza e da miséria, tanto no plano nacional como no da sociedade mundial. Naturalizado brasileiro, tendo com o Brasil um caso de paixão que o fazia sofrer mas também se alegrar, aqui se casou três vezes, tendo em seu primeiro matrimônio com Áurea Fuks seu único e muito querido filho, Daniel. Passou seus últimos dez anos com Estrela Bohadana, companheira que, até o instante derradeiro, esteve sempre ao seu lado, velando-o, confortando-o, amando-o.

Pouco depois de seu sepultamento, Bernardo Sorj, companheiro de René de todas as horas, abraçando-me com tristeza, disse-me entre lágrimas que estávamos os dois mais pobres. Sem conforto, vejo-me obrigado a reconhecer a justeza de suas palavras, sem sequer poder remediar a minha dor. Estamos todos nessa situação, seus parentes, seus amigos mais próximos e as ciências sociais no Brasil e em toda a parte.

Cuidaremos, portanto, para que sua memória permaneça entre nós, providenciando a realização de solenidades que façam com que, na nossa querida UFF e fora dela, seu espírito sirva e permaneça como exemplo e guia das novas gerações.

Rio de Janeiro, 5 de maio de 2003

Eurico de Lima Figueiredo

Chefe do Departamento de Ciência Política

Universidade Federal Fluminense 